NBER WORKING PAPER SERIES

\title{
HOW WIDE IS THE SCOPE OF \\ HOLD-UP-BASED THEORIES? \\ CONTRACTUAL FORM AND MARKET \\ THICKNESS IN TRUCKING
}

\author{
Thomas N. Hubbard \\ Working Paper 7347 \\ http://www.nber.org/papers/w7347 \\ NATIONAL BUREAU OF ECONOMIC RESEARCH \\ 1050 Massachusetts Avenue \\ Cambridge, MA 02138 \\ September 1999
}

This paper was previously part of "Governance in the Deregulated Trucking Industry." I would like to thank Alya Hidayatallah for excellent research assistance and comments, and Michael Crum, Benjamin Klein, Julie Mortimer, seminar participants at UC Berkeley, Rochester, Michigan, Chicago, Wisconsin, Harvard, USC, and UCLA, and various individuals at trucking firms and associations for helpful discussions. The views expressed herein are those of the authors and not necessarily those of the National Bureau of Economic Research.

(C) 1999 by Thomas N. Hubbard. All rights reserved. Short sections of text, not to exceed two paragraphs, 
may be quoted without explicit permission provided that full credit, including $\odot$ notice, is given to the source. How Wide Is the Scope of Hold-Up-Based Theories?

Contractual Form and Market Thickness in Trucking

Thomas N. Hubbard

NBER Working Paper No. 7347

September 1999

JEL No. L22, L42

\title{
ABSTRACT
}

How far do the contractual implications of hold-up-based theories (Klein, Crawford, and Alchian (1978), Williamson $(1979,1985))$ extend? I investigate this in the context of trucking. Quasi-rents in trucking are generally smaller than in the contexts studied in the previous empirical literature. They vary with hauls' distance and the thickness of local markets. I find that doubling the thickness of the market increases the likelihood that simple spot arrangements govern transactions by about $30 \%$ for long hauls. I find weaker evidence of relationships between local market thickness and contractual form for short hauls -- hauls for which quasi-rents are particularly small. Contracts' role as protectors of quasi-rents becomes less important as quasi-rents decrease, but exists over a surprisingly large range.

\author{
Thomas N. Hubbard \\ Graduate School of Business \\ University of Chicago \\ 1101 E. 58th St. \\ Chicago, IL 60637 \\ and NBER \\ thomas.hubbard@gsb.uchicago.edu
}




\section{Introduction}

A central proposition of hold-up-based theories (Klein, Crawford, and Alchian (1978), Williamson $(1979,1985)$; see also Grossman and Hart (1985)) is that firms will substitute more complicated contractual arrangements for simple spot arrangements when transactions involve relationship-specific investments. Early work found evidence in favor of this proposition in several procurement contexts, including auto parts (Monteverde and Teece (1982)), aerospace components (Masten (1984)), natural gas (Masten and Crocker (1985)), and coal (Joskow (1985, 1987)). Investments in these contexts are generally large and sunk over long horizons. Appropriable quasirents tend to be correspondingly large when these investments are also relationship-specific. This literature established that hold-up-based theories can have predictive content. But it says less about the theories' scope because it examines contexts in which the theories are most likely to hold. ${ }^{1}$

This paper examines these theories' scope. The issue of scope is important because most transactions do not involve assets which are as relationship-specific as those examined in the previous literature. Specificity instead arises for more mundane reasons such as search or transportation costs, or temporal mismatches between supply and demand (Masten, Meehan, and Snyder (1991)). Quasi-rents arise in search (Diamond (1971)) and switching cost (Klemperer (1987)) models in much the same way as in hold-up-based theories. In all of these models, agents' actions can transform competitive situations to monopolistic or monopsonistic ones.

How far do the contractual implications of hold-up-based theories extend? How large and long-lasting must quasi-rents be for firms to mitigate incentive conflicts with formal contractual arrangements?

I investigate these issues in the context of trucking. Trucking is an interesting context for such an investigation because assets are rarely specific to users over long horizons. Assets are less specific than in most situations previously examined by the empirical literature. Quasi-rents are smaller and only exist in the short- and medium-run. Quasi-rents arise for two reasons relevant to this paper. First, trucks and trailers can be specific to users in the very short run. When trucks arrive to pick up goods, quasi-rents arise because it is costly for carriers to redeploy them to serve

${ }^{1}$ Pirrong (1993) is an exception. See below. 
other customers. ${ }^{2}$ These quasi-rents are generally small because trucks and trailers are very mobile, but would vary with the thickness of the local market. Second, in long haul markets, efficient entry involves route-specific investments which lower carriers' cost of filling "backhauls," or return trips. These investments help carriers market service to shippers with demands which complement those of outbound shippers. I will refer to the information garnered by such investments as "route-specific knowledge." These investments are relationship-specific when shipping lanes are thin. Appropriable quasi-rents arise when alternative shippers demanding service on the same outbound route are scarce. These quasi-rents appear over longer horizons than those arising from tractortrailers' specificity because it is less costly to find an alternative shipper in general than one for a specific route. But they are smaller and appear over shorter horizons than in the circumstances studied in most of the early empirical literature. Hold-up-based theories predict that, absent alternative institutional responses, simple spot arrangements will be used less relative to more sophisticated contractual forms when local markets are thin for both short and long hauls.

The empirical work uses data from over 30,000 trucks from the Census' 1992 Truck Inventory and Use Survey. I test for relationships between local market thickness and contractual form separately for hauls of different distances. If they exist for both short and long hauls, this implies that firms use formal contractual arrangements to ameliorate contractual problems arising from tractor-trailers' specificity. If they exist for long hauls but not short hauls, this indicates that they do so in response to appropriation problems related to investments in route-specific knowledge, but not tractor-trailers' specificity. If they appear for neither class of hauls, this implies that firms do not use contractual form to mitigate either of the problems described above. These tests have general implications regarding the scope of hold-up-based theories. Relationships between local market conditions and contractual form for long hauls indicate that the contractual implications of these theories apply beyond situations where asset specificity extends over long horizons. If such relationships exist for short hauls as well, this is evidence that these implications are extremely broad.

The main empirical results follow. For long hauls, long-term contracts are used more relative

${ }^{2}$ This can, of course, be a two-sided problem: carriers can hold up shippers as well. The analysis from shippers' perspective is analogous. 
to simple spot arrangements when local outbound markets are thin, especially when inbound markets are thin as well. Contractual form for these hauls varies with shipping markets' composition and size. The magnitudes of these relationships are economically significant. For example, consider hauls which use a particular type of trailer. Doubling the trailer's share within a region increases the fraction of hauls which are governed by spot arrangements by about $30 \%$. These relationships appear across most trailer types, even those which are not specific to product classes such as basic, enclosed vans. For short hauls, I find relationships between contractual form and market size, but not between contractual form and market composition. These results provide evidence that problems associated with appropriating the value of investments in route-specific knowledge drive contracting decisions. There is less evidence that problems associated with tractor-trailers' specificity to users in the very short run drives these decisions. I conclude that the contractual implications of hold-upbased theories extend beyond circumstances where specific investments are large and sunk. There is some evidence that these implications extend to circumstances where quasi-rents are small and appear only in the very short run, but this evidence is weaker.

These results reinforce and extend the existing literature in several ways. In particular, they expand upon Pirrong's (1993) study, which provides qualitative evidence that contractual form varies with market thickness in the context of ocean shipping. ${ }^{3}$ First, they indicate that hold-upbased theories' scope extends even beyond Pirrong's context; trucking markets are generally thicker than the thickest ocean shipping markets. ${ }^{4}$ Second, they suggest a bound to these theories' predictive scope. Differences in the composition of local markets do not explain differences in contractual form when markets are as thick as those in local trucking. Third, they are quantitative rather than qualitative. To my knowledge, this paper is the first to quantify relationships between market

${ }^{3}$ They are also complementary to Nickerson and Silverman (1996), who find that relationship-specific investments affect contractual relationships between carriers and drivers. See Palay (1984) for specificity and governance in rail shipping.

${ }^{4}$ The thickest local market Pirrong examines is grain shipments originating on the lower Mississippi River. On average, about 10 ships/day load grain in this market. This is thinner than nearly all trucking markets covering regions of comparable size. For example, the Census' Truck Inventory and Use Survey estimates that 20-60 trucks based in each of South Dakota, Kansas, and Nebraska - states not noted for forestry - haul goods using logging trailers. 
thickness and contractual form.

The rest of the paper is organized as follows. Section 2 characterizes the contractual forms used in trucking, describes how appropriable quasi-rents arise within motor carriage transactions, and develops the hypotheses to be tested. Section 3 presents the data, proposes measures of local market conditions, and depicts general relationships between contractual form and these measures. Section 4 contains the estimation results and the results and implications of the hypothesis tests. It also investigates the alternative hypothesis that relationships between contractual form and local market conditions reflect competition from rail and other substitute shipping modes rather than contractual issues. Section 5 concludes.

\section{Contractual Form and Asset Specificity in Trucking}

Shippers and carriers make a series of long-, medium-, and short-run decisions that determine output and the terms of trade. ${ }^{5}$ Shippers' long-run decisions include entry into product markets and any large, sunk capital investments such as manufacturing plants. Similarly, carriers' long-run decisions include terminals and other infrastructural investments. Shippers and carriers make medium-run decisions taking these as given. Medium-run decisions are made over horizons of roughly six months to one year. These include how much route-specific knowledge to acquire. They also include equipment purchases and any long-term contractual arrangements. Equipment purchases determine the size and composition of firms' owned tractor-trailer fleets. Contractual arrangements include those between shippers and for-hire carriers, and between firms and equipment leasing companies. These medium-run decisions are based on demand forecasts and anticipate that short-run production-related decisions will be profit-maximizing. Shippers' demand for motor carriage reflects trade patterns with their customers. In most cases, this demand is consistent and periodic.

Firms' medium-run decisions determine shipping transactions' contractual form. In this paper, contractual form means whether shippers haul their own goods, and whether transactions with

${ }^{5}$ Throughout this paper, "shippers" refers to firms or divisions demanding transportation services (e.g. manufacturing divisions) and "carriers" refers to those supplying such services. When firms choose to haul their own goods, "shippers" and "carriers" are divisions of the same firm. 
for-hire carriers are mediated by formal long-term contracts or a series of simple spot arrangements. When individual firms either ship multiple products or ship products over various distances, different contractual forms may be used for each product-distance combination. Although shippers and carriers seek to maximize profits individually, it is in their mutual interest to choose efficient contractual forms, where efficiency reflects both production and transaction costs.

Three contractual forms mediate trade between shippers and carriers: private carriage, contract carriage, and common carriage. These correspond to situations where the terms of trade take the form of vertical integration, long-term contracts, and spot arrangements. Distinctions among these forms follow distinctions laws and regulations made among firms when the industry was heavily regulated (roughly, between 1935 and 1980). Private carriage is when shippers haul their own goods using internal dispatching systems and employee drivers. The terms of trade in contract and common carriage differ both in the length of the agreement and its specificity to shipper-carrier combinations.

Bills of lading contain the terms of trade under common carriage. These documents cover individual shipments. They are standard forms which contain the names of the shipper and carrier, the origin and destination, the volume, the type of commodity, the price (or "rate"), whether the shipment is prepaid or collect, and any equipment or handling requirements (such as for refrigerated or fragile goods). The incentive provisions in bills of lading are not specific to hauls, carriers, or shippers. For example, bills of lading almost always contain standard provisions describing the extent of carriers' liability, but generally do not have provisions which specify delivery windows or penalties for late arrivals. ${ }^{6}$ A distinguishing characteristic of common carriage is that there are no formal incentive provisions that are specific to the transactional relationship.

ICC regulations covered common carriage rates during the period under study, but these regulations had little effect on shipping markets because the ICC had little interest in forcing firms to abide by their spirit. Between 1983 and 1994, regulations required carriers to file common carriage

${ }^{6}$ For example, the Uniform Straight Bill of Lading put forth by the American Trucking Associations states: "Unless arranged or agreed upon, in writing, prior to shipment, carrier is not bound to transport a shipment by a particular schedule or in time for a particular market, but is responsible to transport with reasonable dispatch." 
rates that were non-discriminatory and required a five-day advance notice for most increases. However, in practice, the term "common carriage" was a misnomer: common carriage rates were negotiated prices which could effectively be changed in the very short run. Carriers could discriminate among shippers by defining the circumstances in which common carriage rates applied very narrowly (for example, between two street addresses). Filed rates usually exceeded market prices by a considerable amount. Carriers and shippers negotiated discounts which then could be renegotiated in the very short run.

Motor carrier contracts contain the terms of trade under contract carriage. These always cover multiple hauls. They can be costly to construct even absent substantial disagreements because they are legal documents which contain provisions specific to carrier-shipper pairs. ${ }^{7}$ As a consequence, they usually cover hauls over reasonably long periods: six months to two years. Prices are usually stipulated in terms of rate formulas which are based on mileage and sometimes fuel prices. Contracts often contain take-or-pay provisions that guarantee carriers minimum freight volumes. Such provisions, combined with renegotiation costs, may limit bargaining during the period contracts cover. Contracts also usually contain more detailed incentive provisions than bills of lading. For example, many specify service requirements; these can include delivery windows and the penalties which apply when shipments are late. Many also contain provisions which restrict carriers' ability to use equipment to serve other shippers. Such provisions serve to "dedicate" part of carriers' fleets to individual shippers. ${ }^{8}$ Unlike common carriage agreements, motor carriage contracts contain formal incentive provisions that can be enforced by third parties. Although minimum purchase guarantees and exclusivity clauses can serve multiple purposes, one purpose can be to protect against quasi-rent appropriation. Using formal contracts provides firms more legal recourse than relying only on informal self-enforcing arrangements.

Asset Specificity in Trucking

Several well-known theories describe how relying on simple spot arrangements to mediate

${ }^{7}$ Even the simplest contracts require the services of a transportation lawyer.

${ }^{8}$ Braunschweig, Crum, and Allen (1995) report survey results which indicate that minimum volume, service quality, and dedicated service provisions are common elements of motor freight contracts. 
trade can be inefficient when transactions involve the use of specific assets. As emphasized by Klein, Crawford, and Alchian (1978), assets' specificity to individual users creates quasi-rents which are potentially appropriable by one or more parties. Quasi-rents' appropriability can lead to inefficiencies which appear in several forms, including underinvestment in specific assets, the expenditure of resources toward enhancing bargaining positions, and low levels of trade. Klein, Crawford and Alchian (1978), Williamson (1979, 1985), and others argue that buyers and sellers may substitute more sophisticated contractual relationships for simple spot arrangements when transactions involve relationship-specific investments. Contracts or, in more extreme cases, vertical integration may mitigate the inefficiencies that would arise if trade were mediated instead by a series of simple spot arrangements.

In trucking, appropriable quasi-rents can arise in two ways relevant to this study. One way is that trucks and trailers can be specific to individual shippers in the very short run. The logic is simple, and is closely related to that described in Pirrong (1993) in the context of ocean shipping. When a truck pulls up to a loading dock, quasi-rents are created which are potentially appropriable. At that point, it is costly for the carrier to use the truck to serve another shipper. It must identify an alternative customer and incur time and transportation costs to move the truck to a new loading dock. Moreover, it may be costly for the shipper to be served by another carrier, also because of search and time costs. These quasi-rents would generally be small, but would vary systematically with the thickness of local shipping markets. In markets where few local shippers demand service which uses a particular type of trailer, carriers may have to wait longer, travel greater distances, or attach a different trailer to use a truck-tractor to serve alternative shippers.

The other way appropriable quasi-rents can arise is relevant for long hauls but not short hauls. Long-haul markets differ from short-haul markets because of the importance of lining up backhauls. Shippers and carriers are imperfectly informed about short run supply and demand on individual routes in the very short run. Unlike, for example, stock exchanges, markets are decentralized. Route-specific investments can enable carriers to obtain better matches to their outbound hauls. This, in turn, lowers the effective cost of outbound hauls. For example, if carriers can identify shippers which frequently ship goods in the opposite direction and coordinate schedules, they can utilize capacity at a higher rate. Route-specific investments are relationship-specific when city-pair 
markets are thin. If carriers cannot easily find and serve other shippers with similar demands, part of the value of these investments depends on serving specific shippers. Appropriable quasi-rents, and associated bargaining problems, arise.

Interstate trucking deregulation removed regulatory barriers which had prevented carriers from entering city-pair markets. Most carriers that offer local service in a given area are potential entrants into long-haul markets originating from the same area. In this sense, long-haul markets are as competitive as short-haul ones. Efficient entry into long-haul markets generally requires sunk route-specific investments, however. Ex ante competitive situations thus can become ex post monopolistic ones when outbound shipping lanes are thin.

\section{Empirical Tests and Alternative Hypotheses}

The source and magnitude of appropriable quasi-rents thus vary for hauls of different lengths. Therefore, testing for relationships between local market conditions and contractual form separately for hauls of different distances provides information regarding which appropriation problems firms address with formal contracts. The results of these tests are generally important because they carry implications for hold-up-based theories' scope.

I first test for relationships between contractual form and local market conditions for short hauls. If such relationships exist, this implies that firms use contractual form to mitigate appropriation problems arising from tractor-trailers' specificity to users in the very short run. If such relationships do not exist, this implies either that appropriation problems do not exist or they are mitigated in ways that do not involve formal contracts -- for example, reputation-based incentive mechanisms suffice.

I then test for relationships between contractual form and market conditions for hauls of longer distances. If they exist for long hauls but not short ones, this implies that firms use contracts to address appropriation problems associated with route-specific knowledge. Contractual form does reflect problems associated with quasi-rent appropriation, but only those in which assets are specific beyond the very short run. One would then conclude that hold-up-based theories' contractual implications are quite broad -- the quasi-rents associated with route-specific knowledge are probably smaller than those which arise with respect to the large, sunk investments studied in other contexts -but not so wide as to cover circumstances where quasi-rents are small and appear only in the very 
short run. Finding that relationships exist for neither short nor long hauls implies that firms do not use formal arrangements to mitigate either of the appropriation problems described above. Such a result would provide evidence against the idea that the contractual implications of hold-up-based theories generally extend to situations where investments are neither large nor relationship-specific over long horizons.

Relationships between contractual form and local market conditions may arise for production-cost-related reasons as well as quasi-rent-related reasons. Some empirical relationships which may reflect appropriation problems may reflect other phenomena as well. For example, contractual form is affected by the volume of goods shippers ship. Trucking specialists generally have a comparative advantage over non-trucking-specialists in achieving scale economies because they can aggregate demands of different shippers at lower cost. ${ }^{9}$ This comparative advantage is smallest when shippers ship large volumes. The choice between contract and common carriage may also be related to shipping volumes. Contract carriage is less advantageous when shippers ship small volumes because of the fixed cost of constructing contracts. This is an issue because shipping volumes are not observed in the data, and may differ systematically across trailer types. Specialized trailers such as grain bodies or logging trailers tend to haul goods for which shipment volumes are high. Relationships between trailers' physical characteristics and contractual form may reflect this as well as appropriation problems.

As a consequence, the primary economic inferences are based on relationships between local market conditions and contractual form, conditional on trailers' physical characteristics. Tests compare, for example, contractual form for hauls using logging trailers in regions where there are few local users versus many (for instance, Kansas versus Oregon). A maintained assumption throughout is that the volume individual shippers ship does not systematically differ with local market conditions. This may not strictly hold, but if high-volume shippers tend to be located in thick local markets, shipping volumes' effect on contractual form would work in the opposite direction

${ }^{9}$ See Keeler (1989) for scale economies in trucking. One explanation for specialists' competitive advantage relies on "coordination economies" similar to those in Bagwell and Ramey (1994). Shippers uncertain about which carriers serve which routes economize by calling for-hire carriers first. 
from contractual difficulties' effect. The former would lead to more private and contract carriage in thicker markets. Finding that the opposite is true suggests the interpretation that problems associated with quasi-rent appropriation affect contractual form. ${ }^{10}$

A second, related issue is that trucking specialists' production-cost-related advantage is likely to differ with local market conditions. This advantage is due to their ability to aggregate different shippers' demands. It is small when local markets are thin. Relationships between local market thickness and the margin between internal and external procurement may not reflect responses to contractual problems, but rather the familiar principle that specialization is limited by the size of the market. Sterner tests of whether concerns about quasi-rent appropriation affect contractual form are based on relationships between local market conditions and contractual form, given external procurement. One would not expect trucking specialists' comparative advantage in production to affect the choice between common and contract carriage, since the relevant margin is between two forms of external procurement. This will be a maintained assumption when interpreting the empirical results. Although the empirical work reports relationships between local market conditions and contractual form in general, the main economic inferences are based on the estimates which explain the margin between common and contract carriage -- in particular, relationships between local market thickness and this margin.

A third issue is whether it is possible to distinguish hypotheses in which contractual arrangements mitigate problems arising from opportunistic behavior from hypotheses in which arrangements merely coordinate supply. An example of the latter is the following. Suppose shippers anticipate that they will demand service at some point in the future, but are uncertain whether supply will exist at that point - perhaps because all capacity in the market is in use. They then would have incentives to make arrangements with carriers to ensure supply, particularly when markets are thin. Forward contracts can arise even when parties are unconcerned about opportunistic behavior. If coordination of this sort requires formal, legally-enforceable agreements, the empirical work cannot distinguish between opportunism- and coordination-based theories.

But it is not clear why firms would bear the additional cost of formalizing agreements absent

\footnotetext{
${ }^{10}$ The bias works in the wrong direction if, for example, plant size is systematically higher in thin local markets than in thick ones.
} 
concerns about contractual fulfillment. Absent such concerns, shippers could ensure supply by simply contacting carriers and asking them to reserve capacity. The value of formalizing arrangements in a legally-enforceable document is clearer when their purpose is to mitigate incentive conflicts: shippers and carriers have more recourse should their trading partner renege. Because the empirical tests are based on a margin that distinguishes between contractual forms in which incentive provisions are informal and formal, I will interpret the results using theories in which contracts address incentive conflicts.

\section{Data}

The data are from the 1992 Truck Inventory and Use Survey (TIUS). The TIUS is a mail-out survey taken by the Bureau of the Census as part of the Census of Transportation. The Census sends survey forms to a random sample of truck owners. The survey asks questions about trucks' characteristics: for example, their type (e.g., pick-up, truck-tractor), make, model, and after-market equipment. It also asks questions about how trucks are used. These questions obtain variables which indicate how far trucks operated from their base, the class of trailer to which they were commonly attached, and the product class they generally hauled. The survey also asks whether trucks were part of private or for-hire fleets. If trucks were for-hire, it asks whether they operated primarily under common or contract carriage. This paper uses only observations of truck-tractors - the front halves of tractor-trailer combinations - and excludes truck-tractors that are: used primarily for personal transportation, rented out by the day, used to haul waste, or not used to haul goods. ${ }^{11}$ It also excludes the small fraction of trucks used mainly for "exempt" carriage: interstate hauls to which ICC regulation traditionally did not apply. The data do not indicate contractual form for such trucks. The final sample includes 32,015 trucks. ${ }^{12}$

\footnotetext{
${ }^{11}$ The latter excludes trucks which are used to transport trailers which have cranes or large winches permanently attached.

${ }^{12}$ The Survey oversamples trucks registered in less-populous states. All of the analysis in this paper uses the weights provided by the Census to adjust for oversampling. See Bureau of the Census (1995) and Hubbard (1998) for more details regarding the data.
} 
Table 1 shows basic patterns in contractual form during 1992. ${ }^{13}$ Trucks are classified according to whether they are used primarily for common, contract, or private carriage. Overall, about $55 \%$ are used for private carriage. Slightly over half of the rest are used to haul goods under common carriage agreements. The table breaks out these shares according to the type of trailer to which trucks are normally attached. "Specialized vans" includes insulated, non-refrigerated vans, drop frame (side-loading) vans, and open-top vans. "Specialized trailers" includes all trailer types not otherwise classified; grain bodies, livestock trailers, and logging trailers are the most common in this category. There is a general correspondence between contractual form and trailers' specificity to uses. Trucks commonly attached to basic vans tend to operate under common carriage more than trucks attached to most other trailers. Correspondingly, trucks attached to specialized trailers tend to operate under private carriage.

Trailer Type, Local Market Conditions, and Contractual Form

I now introduce the variables used to proxy for cross-sectional differences in local market conditions. One of these is "trailer density." The formula is:

$$
T D_{j k}=\frac{\text { number of state } k \text { trucks with trailer } j \text { as their principal trailer }}{\text { developed area of state } k}
$$

I calculate the numerator from the individual observations in the TIUS and the sampling weights provided by the Census. Trucks' state corresponds to where they are based, not where they are registered or the headquarters of the firm that owns them. The denominator is computed using data summarized in the 1998 Statistical Abstract of the United States (Bureau of the Census (1998)) from the Department of Agriculture's National Resources Inventory. "Developed area" includes urban and built-up areas of 10 acres or more, and is measured in square miles. ${ }^{14}$ Trailer density captures

\footnotetext{
${ }^{13}$ Because observations of trucks rather than hauls and the calculations do not adjust for differences and changes in intensity of use, the shares in table 1 indicate capacity shares rather than output shares.

${ }^{14}$ Only about $4.7 \%$ of land in the U.S. is developed. This ranges from over $30 \%$ in New Jersey to less than $1 \%$ in Wyoming, Nevada, and Alaska. Alaska and Hawaii are excluded from the analysis.
} 
both the composition and density of state k's fleet - i.e., state k's trailer and truck capacity normalized by a measure of geographic area. Because capacity measures reflect aggregate demand, trailer density (and other measures of local market conditions) have demand- as well as supply-side interpretations. The composition of the fleet reflects the composition of shipping demand. Likewise, fleet density reflects the density of shippers.

One can break trailer density down into components that reflect composition and density:

$$
T D_{j k}=\frac{\text { trailers }_{j k}}{\text { area }_{k}}=\frac{\text { trailers }_{j k}}{\text { trucks }_{k}} \frac{\text { trucks }_{k}}{\text { area }_{k}}=T S_{j k} T A_{k}
$$

$\mathrm{TS}_{\mathrm{jk}}$ is "trailer share": the fraction of state k's fleet which is principally attached to trailer type $\mathrm{j} . \mathrm{TA}_{\mathrm{k}}$ is trucks/area for state $\mathrm{k}$. Note that $\ln \left(\mathrm{TD}_{\mathrm{jk}}\right)=\ln \left(\mathrm{TS}_{\mathrm{jk}}\right)+\ln \left(\mathrm{TA}_{\mathrm{k}}\right)$. Including $\ln (\mathrm{TD})$ in a model to capture differences in market thickness is identical to including both $\ln (\mathrm{TS})$ and $\ln (\mathrm{TA})$ and restricting their coefficients to be the same. One can test this restriction by including $\ln (\mathrm{TS})$ and $\ln$ (TA) separately and testing the equality of the coefficients. Finding differences implies that the composition and general density of the market (as measured) affect contractual form differently.

These measures are not perfect. Ideally, one would base measures on narrower definitions that capture market thickness better. For example, these measures do not capture differences in local market conditions within states. Thus, empirical work which identifies parameters using regional differences is limited to doing so using cross-state differences. In addition, TD and TA may capture "average" cross-state differences in local markets poorly, because they do not account for cross-state differences in the agglomeration of shipping markets (and economic activity in general). Normalizing by developed area makes markets in states where developed area is dispersed (such as Iowa) look thick relative to those where it is agglomerated (such as Nevada). ${ }^{15}$

Measurement error thus may bias estimates of coefficients on $\ln (\mathrm{TD})$ and $\ln (\mathrm{TA})$. One can check whether this is the case by replacing $\ln$ (TA) with state fixed effects (or, equivalently, including

\footnotetext{
${ }^{15}$ To see this, compare two states. Suppose that they have identical economies except that in one, all activity is within a single city, but in the other, it is evenly divided into two equallysized cities, one hundred miles apart. TD and TA would be the same in both states, but market thickness is greater in the first because there would be more alternative local users for a given piece of equipment.
} 
fixed effects with $\ln (\mathrm{TD})$ ). This allows one to estimate relationships between market composition and contractual form even if regional differences in density and size are not captured well by TD and TA. In the results section, I report and interpret coefficients on $\ln (\mathrm{TD})$ and $\ln (\mathrm{TA})$. Concerns about measurement error mean that these provide weaker evidence than coefficients which indicate relationships between contractual form and measures of market composition.

A second issue related to these proxies is that they reflect where trucks are based, not necessarily where they haul. Long-haul shipping markets are based on origin-destination pairs. Ideally, measures of market thickness should be based on the density of individual shipping lanes, not characteristics of one of the endpoints. The proposed proxies work well for long hauls if the density of shipping lanes emanating from a state is highly correlated with characteristics of its trucking fleet. There is reason to believe that this condition holds. For example, one would expect the density of long-haul shipping lanes involving states with large trucking fleets relative to their area to be high (higher in shipping lanes involving New Jersey those involving New Mexico) and to be related to fleets' composition (higher for hauls using logging trailers in Oregon than in Kansas).

Tables 2-4 depict relationships between contractual form and both TA and TS during 1992. Table 2 reports private and common carriage shares for the bottom and top five states ranked by trucks/developed area. Trucks/developed area is highest in states where economic activity is most concentrated in large cities. Contractual form shares vary considerably among the states classified as "bottom five" and "top five." The private carriage share tends to be lower and the common carriage share tends to be higher for the "top five" than the "bottom five." Shorter-term contractual arrangements are more prevalent in states with dense markets. Internal procurement is less prevalent.

Table 3 summarizes within-state trailer shares. Averaging across states, the mean share of basic vans is $29.2 \%$. The mean share is lower for hauls using more specialized equipment, particularly for those grouped in "specialized vans" and "specialized trailers." For each trailer type, trailer shares vary considerably across states; this variation is important for identifying relationships between local market conditions and contractual form. Variation is particularly large for the most common trailer types. For example, basic vans' share ranges from $6.7 \%$ in Wyoming to $54.4 \%$ in Tennessee. The states in which the share of the "specialized trailers" is highest are regions from 
which shipments of autos, grain, livestock, and logs tend to originate. Trailer shares reflect crosssectional differences in what is shipped from each state. The right two columns show the class of products most commonly shipped on each trailer type, and a Herfindahl-like measure of trailers' specificity to product classes. The latter is constructed as follows. I classify the trucks according to trailer type. Within each class, I then calculate the fraction that are used primarily to transport each product class in the data. Call this fraction $\mathrm{s}_{\mathrm{ij}}$, where $\mathrm{i}$ indexes the trailer type and $\mathrm{j}$ indexes the product class. ${ }^{16}$ The concentration measure is $\mathrm{H}_{\mathrm{i}}=\sum_{j=1}^{J} s_{i j}^{2}$, where $\mathrm{J}$ is the number of product classes. This rough measure confirms the intuition that basic vans and platforms are least specific to product classes, and that auto trailers and "specialized trailers" are the most specific.

Table 4 shows the fraction of trucks operating under private and common carriage, by trailer type. The left column of each panel reports these fractions calculated across the entire sample. The right column contains analogous proportions calculated across only the three states for which trailer shares are highest for each trailer type. Comparing the two columns in the left panel, common carriage has a higher average share for the "top three states" than the sample mean for all trailer types except platforms. This suggests that contractual form, given outside procurement, is influenced by the composition of the local fleet. In the right panel, private carriage has a much smaller than average share for the "top three states" than the sample mean for all of the vans and tank trucks except drop frame vans. The make-or-buy decision varies with market composition for hauls using these trailers. Similar differences do not appear for the specialized trailers.

Cross-tabulations indicate that relationships exist between contractual form and local market conditions. The following section explores these relationships further. I first test the hypotheses outlined in the previous section. I then investigate whether relationships between local market conditions and contractual form arise for reasons having to do with selection. Finally, I test whether relationships between local market conditions and contractual form are strongest in states with the thinnest backhaul markets.

\section{Results}

Tables 5-7 contain results from ordered logit specifications. The dependent variable is equal

\footnotetext{
16"Product classes" are those in Hubbard (1998). They are broadly defined: for example, "processed food," "building materials," "transportation equipment."
} 
to zero, one, and two if the truck is used primarily for common, contract, and private carriage, respectively. The "primary use" criterion employed by the Census means that for medium- and longhaul trucks, the dependent variable corresponds to the contractual form primarily used for outbound hauls.

The ordered logit specification implies:

$$
\begin{gathered}
P(\text { common })=\frac{e^{-X \beta_{1}}}{1+e^{-X \beta_{1}}} \\
P(\text { private })=\frac{1}{1+e^{-X \beta_{2}}} \\
P(\text { contract })=1-P(\text { common })-P(\text { private })
\end{gathered}
$$

where $\mathrm{X}$ includes a constant. $\beta_{1}$ and $\beta_{2}$ are coefficients which estimate relationships between the variables in $\mathrm{X}$ and the common/contract and contract/private margins, respectively. Positive estimates of these coefficients identify variables associated with longer-term arrangements. This specification differs slightly from most ordered models because I allow the explanatory variables to affect the two margins differently.

Table 5 summarizes results from basic specifications. The three panels use samples of trucks which primarily operate within 50 miles, between 50 and 200 miles, and over 200 miles from their base. In these specifications, $\mathrm{X}$ includes a constant, a vector of dummy variables indicating the trailer type to which the truck was generally attached, a "mixed cargo" dummy that equals one if the truck generally carried cargo from multiple product classes and zero otherwise, and $\ln ($ trailer density). The mixed cargo dummy is an indicator for trucks used for "less-than-truckload" hauls. These hauls are generally governed by short- term arrangements due to lower shipping volumes and efficiencies of consolidation. The coefficients of interest in these specifications are those on $\ln$ (trailer density), particularly those explaining the margin between common and contract carriage.

The main result from these specifications is that simple spot arrangements are used more when markets are thick, especially for longer hauls. The coefficient on $\ln$ (trailer density) at the common/contract margin is negative and significant for each of the distance categories. Spot arrangements are used less when trailer density is low. The short-haul coefficient suggests that tractor-trailers' specificity in the very short run affects contractual form. The fact that the medium- 
and long-haul coefficients are larger suggests that specificity arising from route-specific knowledge affects contractual form. These results imply that the contractual implications of hold-up-based theories extend well beyond circumstances where investments are large and relationship-specific over long horizons.

Table 6 reports probability derivatives for $\ln$ (trailer density). These indicate predicted changes in contractual form from doubling trailer density, which corresponds roughly to moving from the $25^{\text {th }}$ to the $50^{\text {th }}$, or the $50^{\text {th }}$ to the $75^{\text {th }}$ percentile values. Holding all explanatory variables at their sample means, an interquartile change in trailer density increases the common carriage share for long hauls by 8.6 percentage points, or $28.1 \%$. It increases the common carriage share for medium hauls by 5.2 percentage points, or $32.6 \%$, and for short hauls by 2.5 percentage points, or $21.5 \%$. The empirical relationships between market thickness and contractual form thus are not only statistically significant, but economically important.

Other patterns in table 5 may reflect problems associated with quasi-rent appropriation, but have other interpretations as well. In particular, the $\ln$ (trailer density) coefficients on the contract/private margin are all negative and significant, and are higher in absolute value for longer hauls. Shippers haul their own goods more when local markets are thin. This may indicate the same phenomena as at the common/contract margin, but may also reflect that for-hire carriers cannot achieve scale economies in thin markets ("specialization is limited by the size of the market").

Table 7 contains results from more detailed specifications which further explore relationships between local market conditions and contractual form. These specifications indicate that the factors which identify the results in table 5 for short hauls are different than those which do so for long hauls. The results in table 7 provide weaker evidence that relationships between trailer density and the common/contract margin for short hauls are due to contracting problems.

The results in the left columns are from specifications which allow relationships between trailer density and contractual form to differ across trailer types. Whereas the coefficients on trailer density in table 5 exploit differences across trailer types and geographic regions, the coefficients on the interactions exploit only geographic differences. I report only the interaction coefficients here; the specification includes the same control variables as above. Considering the common/contract margin for short hauls, only three of the interaction coefficients are negative and statistically 
significant. In contrast, almost all of the interactions are negative and statistically significant for medium and long hauls. Relationships between trailer density and spot contracting persist across a wide range of trailers for medium and long hauls, but not for short hauls.

The middle columns break $\ln$ (trailer density) into components which reflect differences in the size and composition of local markets: $\ln$ (trailer share) and $\ln$ (trucks/area). The coefficient on $\ln ($ trucks/area) is negative and statistically significant for each distance category; the coefficient on $\ln$ (trailer share) is significant for long and medium hauls. If market thickness for particular trailer types affects quasi-rents' appropriability, then the composition of local markets, conditional on their size, should affect contractual form. Figures 1 and 2 depict the relationship between $\ln$ (trailer share) and contractual form for short and long hauls, respectively. Predicted contractual form shares, holding all variables other than trailer share at their sample means, are on the horizontal axis. Trailer share is on the vertical axis. Figure 1 shows that there is little relationship between trailer share and contractual form for short hauls; the lines depicting the two margins are close to vertical. In contrast, figure 2 shows that the relationship between local market composition and contractual form is strong for long hauls. Moving from a 0.05 share to a 0.10 share increases the probability that hauls are mediated by common carriage arrangements from 0.20 to 0.26 , or $32 \%$. These specifications indicate that market composition and size drive relationships between $\ln$ (trailer density) and contractual form at the common/contract margin for medium and long hauls. However, there is only weak evidence that market composition and contractual form are related for short hauls.

The right columns of table 7 report estimates from specifications which replace $\ln$ (trucks/area) with fixed effects for each state. I report the coefficients on $\ln ($ trailer share). By construction, the coefficients on $\ln ($ trailer share) are the same as one would get if one included $\ln$ (trailer density) instead. The relationship between local market conditions and contractual form is strong for long and medium hauls. Moving from a 0.05 share to a 0.10 share increases the probability that medium and long hauls are mediated by common carriage agreements by $20-25 \%$. I find no relationship between local market conditions and contractual form for short hauls. The statistically significant coefficients reported in table 5 reflect only relationships between contractual form and the general density of states' trucking fleets.

\section{Intermodal Selection Issues}


Figures 1 and 2 raise the question of whether relationships between local market conditions and contractual form are driven by selection. The empirical analysis is conditional on firms choosing to ship by truck. Rail can be a close substitute for trucks for long distance shipping, particularly for goods which are shipped in bulk such as coal, minerals, grain, lumber, and metals. Suppose rail is characterized by large scale economies, and cross-price elasticities between truck and rail are high. Then, looking across local markets, rail's share may be negatively correlated with trailer share. For example, one might observe high rail share and low dump trailer share in regions where mining is important. Despite the fact that the shipping market is thick for products hauled by dump trailers, dump trailers' share of long hauls would be small because the market is large enough to allow scale economies to be achieved in rail. If rail is a closer substitute to common carriage than to contract or private carriage, selection would create relationships between trailer share and contractual form similar to those in figure 2 .

I investigate this in two ways. First, I examine whether trailer share is low where production of products typically hauled by the trailer is high. From table 3, dump trailers' share is very high in Nevada and West Virginia: states that produce the most metallic ores and coal, respectively. It is also high in other major mining states such as Arizona and Kentucky. Similar patterns appear for specialized trailers' shares: grain bodies' share is highest in the major grain-producing states, for example. Trailer share is high, not low, in regions where production of products that are hauled by these trailers is high.

Second, I explore whether trailer share tends to be low in regions where rail share is high. I test for relationships between rail share and trailer share for two product classes which are almost exclusively hauled on platform trailers: lumber and primary metals. The latter includes goods such as pipes, ingots, and sheet metal. The rail share for long (over 250 miles) hauls of these goods is sizeable, but not extremely large: between 25-30\%. Using data from the Census' 1993 Commodity Flow Survey, I compute rail and truck shares for each of these product classes at the state level. Although the level of disaggregation does not allow one to compute these shares for long hauls only, the data contain "average haul distance" at the state*product class level. I use this to control for cross-state differences in haul length. It is not possible to compute rail and truck shares for lumber and primary metals in each state. The Census does not publish quantities when they are not deemed 
statistically reliable or when they would violate confidentiality restrictions. The empirical analysis includes only states for which there are non-missing values for each variable. It thus generally excludes states which ship small quantities of lumber and primary metals. ${ }^{17}$

I regress rail share and (1-truck share) on platform trailer share and average haul distance. (1-truck share) is a measure of all substitutes for truck hauling, which in this case mostly includes barges as well as rail. Platform trailer share is calculated across all trucks within each state. In specifications not reported here, I use an analogous measure calculated across only long haul trucks; the results do not qualitatively differ. Results are in table 8 . The first panel examines lumber shipping. The coefficient on trailer share is positive in both specifications, and is significant in the second. States where the trucking fleet is disproportionately platform trailers are those in which shipping modes other than trucks have high shares for lumber hauls. The results are stronger in the second specification because the variance in the dependent variable is larger: the degree to which lumber is shipped via water differs considerably across states. The trailer share coefficient is not significantly different from zero in the primary metal specifications. The third panel constructs rail share and (1-truck share) from the sum of lumber and primary metal shipments. The results are similar to those in the lumber specification, mainly because lumber shipments are just under three times primary metal shipments. These results provide no evidence of a negative relationship between trailer share and the share of non-truck shipping modes.

Combined, these results do not suggest that shipping mode selection is driving the results in the previous subsection. If anything, selection would work against finding positive relationships between spot contracting and market thickness.

\section{Outbound/Inbound Ratios}

I next explore the hypothesis that relationships between local market thickness and contractual form are due to specific investments which are backhaul-related. Under this hypothesis, one would expect such relationships to be strongest when backhaul markets are thin, because the investments required to identify and serve backhaul customers would tend to be larger.

${ }^{17}$ This sort of cross-sectional test is only possible at all for goods such as lumber or metal that are shipped from many different states. One cannot run similar tests for other products such as coal or ores because few states ship these products in large quantities. 
I test whether relationships between the contractual form used for outbound hauls and local market conditions differ across states along with the ratio of interstate outbound and inbound truck shipments. Backhaul markets tend to be thinner, the higher the outbound/inbound ratio. Using data from the 1993 Commodity Flow Survey, I calculate the volume of outbound and inbound interstate truck shipments for each state. The ratio between these quantities varies considerably, ranging from about 0.5 for Nevada, Delaware, and Massachusetts to about 2.0 for Wyoming, Maine, and Montana. Finding that the relationship between local market thickness and contractual form is strongest for hauls which originate in markets where the outbound/inbound ratio is high is consistent with the hypothesis that relationships between local market conditions and the common/contract margin for medium and long hauls are due to backhaul-related route-specific investments.

The results in table 9 support this hypothesis. In the top panel, the interaction between $\ln$ (trailer share) and $\ln$ (outbound/inbound) is negative and significant for both medium and long hauls. Combined with the coefficient on $\ln$ (trailer share), one can compute the value of outbound/inbound such that the marginal effect of $\ln$ (trailer share) on contractual form is equal to zero. This value is 0.49 for medium hauls, and 0.13 for long hauls; both of these are lower than the minimum in the sample. From the bottom panel, these results do not change qualitatively when one replaces $\ln$ (trucks/area) and $\ln$ (outbound/inbound) with state fixed effects. The outbound/inbound ratio such that the marginal effect of $\ln$ (trailer share) on contractual form equals zero is 0.44 and 0.26 for medium and long hauls, respectively. There is only a weak relationship between local market conditions and the contract/common margin in states where the ratio of outbound to inbound shipments is very low. This relationship becomes stronger as this ratio increases, and is very strong in states where this ratio is high. This is exactly what one would expect if concerns about appropriating the returns from investments in route-specific knowledge cause firms to substitute formal contractual arrangements for simple spot arrangements.

\section{Conclusion}

The contractual implications of hold-up-based theories extend well beyond the situations examined by most of the existing empirical literature. These theories explain differences in contractual form even when quasi-rents are neither large nor appear over long horizons. Their scope approaches situations normally considered in light of search or switching cost models. Contracts 
play a role in mitigating the inefficiencies identified within these other strands of the literature. Quasi-rents do not have to be very large for firms to begin to substitute formal contractual relationships for less formal incentive mechanisms such as self-enforcing arrangements.

Contracts have many potential roles. Future work will investigate contractual form in light of incentive issues other than hold-up, such as agency. This work will test theoretical propositions by examining empirical relationships between the adoption of monitoring technologies and changes in contractual form. These tests will lend further insights regarding the role of long-term contracts and vertical integration in this industry that will complement the main result of this paper: that contracts' role as protectors of quasi-rents does become less important as quasi-rents decline, but exists over a surprisingly large range. 


\section{References}

Bagwell, Kyle, and Garey Ramey, "Coordination, Advertising, and Search Behavior in Retail Markets," American Economic Review, June 1994, 498-517.

Braunschweig, Charles D., Michael R. Crum, and Benjamin J. Allen, "Evolution of Motor Carrier Contracting," Transportation Quarterly, Spring 1995, 99-115.

Bureau of the Census, Truck Inventory and Use Survey: 1992, Washington, 1995.

Bureau of the Census, Statistical Abstract of the United States: 1998, Washington, 1998.

Diamond, Peter A., “A Model of Price Adjustment," Journal of Economic Theory, June 1971, 156168.

Grossman, Sanford, and Oliver Hart, "The Costs and Benefits of Ownership: A Theory of Vertical and Lateral Integration," Journal of Political Economy, 94:691-719.

Hubbard, Thomas N., "Why is Process Monitoring Valuable? The Use of On-Board Information Technology in the Trucking Industry," NBER Working Paper \#6482, 1998.

Joskow, Paul L., "Vertical Integration and Long-Term Contracts: The Case of Coal-Burning Electric Generation Plants," Journal of Law, Economics, and Organization, Spring 1985, 33-80.

Joskow, Paul L., "Contract Duration and Relationship-Specific Investments: Evidence from Coal Markets," American Economic Review, March 1987, 168-85.

Keeler, Theodore E., "Deregulation and Scale Economies in the U.S. Trucking Industry: An Econometric Extension of the Survivor Principle," Journal of Law and Economics, October 1989, $229-53$.

Klemperer, Paul, "The Competitiveness of Markets with Switching Costs," Rand Journal of Economics, Spring 1987, 137-150.

Klein, Benjamin, Robert Crawford, and Armen Alchian, "Vertical Integration, Appropriable Rents, and the Competitive Contracting Process," Journal of Law and Economics, 21(2), 297-326.

Masten, Scott E., "The Organization of Production: Evidence from the Aerospace Industry,” Journal of Law and Economics, October 1984, 403-17.

Masten, Scott E., and Keith Crocker, "Efficient Adaptation in Long-Term Contracts: Take-or-Pay Provisions for Natural Gas," American Economic Review, December 1985, 1083-93. 
Masten, Scott E., James W. Meehan, and Edward A. Snyder, “The Cost of Organization,” Journal of Law, Economics, and Organization, Spring 1991, 1-25.

Monteverde, Kirk, and David J. Teece, "Supplier Switching Costs and Vertical Integration in the Automobile Industry,” Bell Journal of Economics, Spring 1982, 206-13.

Nickerson, Jack A., and Brian S. Silverman, "Determinants of the Employment Relation in For-hire Trucking," mimeo, Washington University, 1986.

Palay, Thomas M., "Comparative Institutional Economics: The Governance of Rail Freight Contracting," Journal of Legal Studies, June 1984, 265-87.

Pirrong, Stephen Craig, "Contracting Practices in Bulk Shipping Markets: A Transactions Cost Explanation," Journal of Law and Economics, October 1993, 937-976.

Williamson, Oliver, "Transaction-Cost Economics: The Governance of Contractual Relations," Journal of Law and Economics, October 1979, 233-261.

Williamson, Oliver, The Economic Institutions of Capitalism, New York, Free Press, 1985. 
</ref_section> 


\section{Table 1}

Contractual Form, by Trailer Type, 1992

$\begin{array}{lcccc} & \text { Common } & \text { Contract } & \text { Private } & \text { N } \\ \text { All } & 24.3 \% & 21.1 \% & 54.6 \% & 32015 \\ & & & & \\ \text { Auto Trailers } & 38.9 \% & 50.6 \% & 10.5 \% & 257 \\ \text { Basic Van } & 36.5 \% & 24.7 \% & 38.8 \% & 9856 \\ \text { Specialized Vans } & 24.3 \% & 18.5 \% & 57.3 \% & 1252 \\ \text { Tank Trucks } & 24.3 \% & 20.6 \% & 55.2 \% & 3224 \\ \text { Refrigerated Van } & 20.1 \% & 28.9 \% & 51.1 \% & 3920 \\ \text { Platform } & 19.9 \% & 22.9 \% & 57.2 \% & 5200 \\ \text { Dump Trailer } & 15.9 \% & 14.9 \% & 69.2 \% & 2670 \\ \text { Specialized Trailers } & 7.7 \% & 6.7 \% & 85.5 \% & 5636\end{array}$




\section{Table 2}

Fraction Private, Contract -- Selected States

\begin{tabular}{lccc} 
& $\begin{array}{c}\text { Trucks/ } \\
\text { Developed Area }\end{array}$ & \% Common & \% Private \\
Bottom Five & & & \\
\cline { 1 - 2 } New Mexico & 2.380 & 13.8 & 82.3 \\
North Dakota & 2.387 & 18.3 & 54.4 \\
South Dakota & 2.511 & 21.4 & 62.1 \\
Virginia & 2.717 & 17.2 & 66.2 \\
Massachusetts & 2.846 & 21.3 & 65.6 \\
Average & & &
\end{tabular}

$\underline{\text { Top Five }}$

$\begin{array}{lccc}\text { Oregon } & 9.270 & 24.9 & 51.7 \\ \text { Nevada } & 9.693 & 21.4 & 67.3 \\ \text { Illinois } & 10.452 & 37.2 & 36.1 \\ \text { California } & 10.481 & 16.6 & 63.1 \\ \text { Utah } & 10.795 & 45.7 & 32.5 \\ \text { Average } & & & \\ \text { Ata } & & 29.2 & 50.1\end{array}$

Developed Area is defined as non-federal urban and built-up areas of 10 acres or greater. See Statistical Abstract of the United States (1998), p. 237. 


\section{Table 3}

\section{Trailer Shares}

1992, by home base state of truck

\begin{tabular}{|c|c|c|c|c|c|c|c|c|}
\hline Trailer Type & $\begin{array}{l}\text { Mean } \\
\text { Share }\end{array}$ & Std. Dev. & $\begin{array}{l}\text { Max } \\
\text { Share }\end{array}$ & $\begin{array}{l}\text { Top } 3 \\
\text { States }\end{array}$ & $\begin{array}{l}\text { Min } \\
\text { Share }\end{array}$ & $\begin{array}{l}\text { Bottom } 3 \\
\text { States }\end{array}$ & Top Product & $\begin{array}{c}\text { Product } \\
\text { Concentration }\end{array}$ \\
\hline Basic Van & $29.2 \%$ & $12.2 \%$ & $54.4 \%$ & TN, NJ, WI & $6.7 \%$ & WY, ID, NM & Processed Food & 0.087 \\
\hline Refrigerated Van & $11.4 \%$ & $5.2 \%$ & $28.9 \%$ & UT, NE, MT & $3.5 \%$ & NM, RI, HI & Processed Food & 0.568 \\
\hline Platform & $15.4 \%$ & $4.1 \%$ & $26.9 \%$ & HI, CA, MT & $8.8 \%$ & NJ, WI, MA & Lumber & 0.107 \\
\hline Dump Trailer & $8.3 \%$ & $5.9 \%$ & $27.0 \%$ & $\mathrm{NV}, \mathrm{HI}, \mathrm{WV}$ & $2.2 \%$ & ME, VT, GA & Building Materials & 0.449 \\
\hline Auto Trailer & $0.7 \%$ & $0.5 \%$ & $2.6 \%$ & MI, NY, FL & $0.1 \%$ & IA, WY, WA & Trans. Equip. & 1.000 \\
\hline \multicolumn{9}{|l|}{ nk Trucks } \\
\hline Tank Truck/Liquid & $7.5 \%$ & $2.9 \%$ & $15.0 \%$ & LA, VT, WY & $3.3 \%$ & SD, OR, WI & Petroleum & 0.308 \\
\hline Tank Truck/Dry & $1.7 \%$ & $0.7 \%$ & $3.9 \%$ & $\mathrm{MT}, \mathrm{MD}, \mathrm{NV}$ & $0.5 \%$ & $\mathrm{RI}, \mathrm{MI}, \mathrm{HI}$ & Building Materials & 0.319 \\
\hline \multicolumn{9}{|l|}{ ecialized Vans } \\
\hline Insulated Van & $1.2 \%$ & $2.1 \%$ & $15.1 \%$ & UT, MN, ME & $0.1 \%$ & $\mathrm{NH}, \mathrm{VT}, \mathrm{MD}$ & Processed Food & 0.387 \\
\hline Drop Frame Van & $2.5 \%$ & $1.2 \%$ & $6.0 \%$ & $\mathrm{MS}, \mathrm{CT}, \mathrm{CO}$ & $0.3 \%$ & VT, HI, IA & Household Goods & 0.256 \\
\hline Open Van & $1.3 \%$ & $1.3 \%$ & $5.6 \%$ & OR, ID, ME & $0.2 \%$ & NV, NE, DE & Logs & 0.249 \\
\hline \multicolumn{9}{|c|}{ ecialized Trailers (selected) } \\
\hline Grain Body & $4.5 \%$ & $5.5 \%$ & $23.7 \%$ & $\mathrm{ND}, \mathrm{SD}, \mathrm{NE}$ & $0.2 \%$ & ME, CT, WV & Farm Products & 0.637 \\
\hline Livestock Trailer & $1.7 \%$ & $2.1 \%$ & $9.3 \%$ & UT, WY, ID & $0.1 \%$ & $\mathrm{RI}, \mathrm{MA}, \mathrm{IL}$ & Livestock & 0.937 \\
\hline Logging Trailer & $3.1 \%$ & $3.5 \%$ & $12.1 \%$ & OR, SC, ME & $1.1 \%$ & RI, NY, KS & Logs & 0.854 \\
\hline
\end{tabular}




\section{Table 4}

Contractual Form Proportions, 1992

by Trailer. All States, Top 3 States.

\section{Common Carriage}

Trailer Type

Basic Van

Refrigerated Van

Platform

Dump Trailer

Specialized Vans

Insulated Van

Drop Frame Van

Open Van

$36.5 \% \quad 54.2 \%$

$20.1 \% \quad 40.8 \%$

$19.9 \% \quad 18.9 \%$

$15.9 \% \quad 17.6 \%$

$\begin{array}{cc}31.2 \% & 76.3 \% \\ 29.8 \% & 30.3 \% \\ 9.4 \% & 25.9 \%\end{array}$

\section{All States Top 3 States}

Specialized Trailers (selected)

$\begin{array}{lcc}\text { Auto Trailer } & 38.9 \% & 56.6 \% \\ \text { Grain Body } & 11.9 \% & 12.8 \% \\ \text { Livestock Trailer } & 16.1 \% & 17.6 \% \\ \text { Pole/Logging Trailer } & 6.2 \% & 8.1 \%\end{array}$

Pole/Logging Trailer

\section{$17.6 \%$
$8.1 \%$}

Tank Trucks

Tank Truck/Liquid

Tank Truck/Dry
$24.7 \%$
$22.5 \%$

Private Carriage

All States Top 3 States

$\begin{array}{ll}38.8 \% & 23.2 \% \\ 51.1 \% & 24.7 \% \\ 57.2 \% & 63.8 \% \\ 69.2 \% & 63.4 \%\end{array}$

$\begin{array}{ll}46.7 \% & 10.6 \% \\ 55.5 \% & 66.3 \% \\ 70.7 \% & 50.7 \%\end{array}$

$70.7 \% \quad 50.7 \%$

$\begin{array}{rr}10.5 \% & 9.0 \% \\ 80.1 \% & 80.5 \% \\ 75.3 \% & 78.3 \% \\ 83.1 \% & 71.7 \%\end{array}$

"Top 3 States" are the states in which trucks using the specified trailer make up the largest fraction of the state's tractor-trailer fleet. 


\section{Table 5}

Ordered Logits - 1992

Dependent Variable: Governance Form

\section{Short Haul Only}

Margin

C1

C2

Refrigerated Van

Platform

Specialized Trailer

Tank Truck

Specialized Van

Dump Trailer

Auto Trailer

Mixed Cargo

$0-50$ Miles

50-100 Miles

100-200 Miles

200-500 Miles

$>500$ Miles

Ln(Trailer Density)

$-\log \mathrm{L}$
Common/Contract Contract/Private Estimate Std. Err. Estimate Std. Err.

$-1.472 \quad 0.083$

$$
0
$$

$\begin{array}{cccc}0.809 & 0.244 & 1.236 & 0.208 \\ 1.172 & 0.149 & 1.136 & 0.113 \\ 1.446 & 0.172 & 1.744 & 0.140 \\ -0.120 & 0.161 & -0.084 & 0.134 \\ 0.751 & 0.334 & 0.082 & 0.233 \\ 0.488 & 0.140 & 0.677 & 0.114 \\ 0.350 & 0.911 & -1.252 & 0.508 \\ -2.739 & 0.108 & -2.832 & 0.128 \\ & & & \\ & & & \\ & & & \\ & & & \\ & & & \\ & & & \\ & & & \end{array}$

Medium Haul Only

Common/Contract Contract/Private Estimate Std. Err. Estimate Std. Err.

$-1.880 \quad 0.071$

\begin{tabular}{llll}
1.468 & 0.188 & 1.057 & 0.113 \\
\hline
\end{tabular}

$\begin{array}{llll}0.157 & 0.092 & 0.240 & 0.074\end{array}$

$\begin{array}{llll}0.019 & 0.130 & 0.346 & 0.105\end{array}$

$\begin{array}{llll}-0.968 & 0.115 & -0.638 & 0.097\end{array}$

$\begin{array}{llll}-0.732 & 0.196 & -0.627 & 0.162\end{array}$

$\begin{array}{llll}-0.618 & 0.117 & -0.657 & 0.097\end{array}$

$\begin{array}{llll}-2.191 & 0.231 & -3.574 & 0.311\end{array}$

$\begin{array}{llll}-2.097 & 0.100 & -2.143 & 0.119\end{array}$

\begin{tabular}{cccc}
-0.346 & 0.055 & -0.437 & 0.046 \\
& & & \\
-0.389 & 0.043 & -0.332 & 0.036 \\
\multicolumn{4}{c}{8172}
\end{tabular}

Long Haul Only

Common/Contract Contract/Private

Estimate Std. Err. Estimate Std. Err.

$-1.403 \quad 0.050$

$\begin{array}{llll}0.025 & 0.067 & -0.200 & \mathbf{0 . 0 6 6}\end{array}$

$\begin{array}{llll}-0.220 & 0.064 & -0.470 & 0.064\end{array}$

$\begin{array}{llll}-0.131 & 0.137 & \mathbf{0 . 3 4 0} & \mathbf{0 . 1 2 3}\end{array}$

$\begin{array}{llll}-0.679 & 0.099 & -0.759 & 0.100\end{array}$

$\begin{array}{llll}-0.856 & 0.136 & -0.463 & 0.139\end{array}$

$\begin{array}{llll}-0.978 & 0.160 & -0.935 & 0.165\end{array}$

$\begin{array}{llll}-1.708 & 0.173 & -3.350 & 0.261\end{array}$

$\begin{array}{llll}-1.409 & 0.075 & -1.342 & 0.102\end{array}$

$\begin{array}{cccc}- & \overline{6} & - & - \\ -0.041 & -0.952 & 0.040\end{array}$

$\begin{array}{llll}-0.405 & 0.035 & -0.421 & 0.036\end{array}$ 


\section{Table 6}

Trailer Density Probability Derivatives

Common Contract Private

Short Haul Trucks

$\begin{array}{llll}\text { Predicted Shares } & 0.115 & 0.101 & 0.784 \\ \text { Probability Derivative } & 0.025 & 0.011 & -0.035 \\ \text { Derivative/Share } & 21.5 \% & 10.6 \% & -4.5 \%\end{array}$

Medium Haul Trucks

Predicted Shares

Probability Derivative

$\begin{array}{lll}0.161 & 0.188 & 0.652 \\ 0.052 & 0.023 & -0.075 \\ 32.6 \% & 12.2 \% & -11.6 \%\end{array}$

Long Haul Trucks

$\begin{array}{lllc}\text { Predicted Shares } & 0.306 & 0.360 & 0.334 \\ \text { Probability Derivative } & 0.086 & 0.008 & -0.094 \\ \text { Derivative/Share } & 28.1 \% & 2.1 \% & -28.0 \%\end{array}$

Note: All calculations use estimates from table 5.

Probability derivatives and predicted shares are calculated at mean value! 


\section{Table 7}

Ordered Logits - 1992: Selected Coefficients

Dependent Variable: Governance Form

\begin{tabular}{|c|c|c|c|c|c|c|c|c|c|c|c|c|}
\hline Margin & $\begin{array}{l}\text { Common } \\
\text { Estimate }\end{array}$ & $\begin{array}{l}\text { Contract } \\
\text { Std. Err. }\end{array}$ & \multicolumn{2}{|c|}{ Contract/Private } & $\begin{array}{l}\text { Common } \\
\text { Estimate }\end{array}$ & $\begin{array}{l}\text { Contract } \\
\text { Std. Err. }\end{array}$ & \multicolumn{2}{|c|}{ Contract/Private } & $\begin{array}{l}\text { Common/ } \\
\text { Estimate }\end{array}$ & $\begin{array}{l}\text { Contract } \\
\text { Std. Err. }\end{array}$ & $\begin{array}{l}\text { Contract/ } \\
\text { Estimate }\end{array}$ & $\begin{array}{l}\text { Private } \\
\text { Std. Err. }\end{array}$ \\
\hline \multicolumn{13}{|l|}{ Short Haul Only } \\
\hline Ln(TD)*Ref. Van & -1.196 & 0.470 & -0.922 & 0.450 & & & & & & & & \\
\hline Ln(TD)*Basic Van & 0.109 & 0.108 & -0.083 & 0.106 & & & & & & & & \\
\hline Ln(TD)*Platform & -0.518 & 0.223 & -0.296 & 0.155 & & & & & & & & \\
\hline Ln(TD)^Spec. Trail. & 0.025 & 0.134 & -0.044 & 0.112 & & & & & & & & \\
\hline Ln(TD)*Tank & -0.174 & 0.132 & -0.278 & 0.110 & & & & & & & & \\
\hline Ln(TD)^Spec. Van & -0.188 & 0.323 & -0.151 & 0.213 & & & & & & & & \\
\hline Ln(TD)*Dump & -0.981 & 0.130 & -0.488 & 0.112 & & & & & & & & \\
\hline Ln(TD)*Auto & - & - & - & - & & & & & & & & \\
\hline Ln(Trailer Share) & & & & & -0.100 & 0.077 & -0.002 & 0.063 & 0.002 & 0.080 & 0.102 & 0.065 \\
\hline Ln(Trucks/Area) & & & & & -0.446 & 0.096 & -0.539 & 0.096 & & & & \\
\hline -LogL & \multicolumn{4}{|c|}{4407} & \multicolumn{4}{|c|}{4417} & \multicolumn{4}{|c|}{4309} \\
\hline \multicolumn{13}{|l|}{ Medium Haul Only } \\
\hline Ln(TD)*Ref. Van & -0.408 & 0.378 & -0.749 & 0.207 & & & & & & & & \\
\hline Ln(TD)*Basic Van & -0.297 & 0.093 & -0.563 & 0.085 & & & & & & & & \\
\hline Ln(TD)*Platform & -0.554 & 0.128 & -0.446 & 0.099 & & & & & & & & \\
\hline Ln(TD)*Spec. Trail. & -0.339 & 0.087 & -0.224 & 0.068 & & & & & & & & \\
\hline Ln(TD)*Tank & -0.141 & 0.085 & -0.024 & 0.075 & & & & & & & & \\
\hline Ln(TD)*Spec. Van & -0.540 & 0.179 & -0.267 & 0.142 & & & & & & & & \\
\hline Ln(TD)*Dump & -0.784 & 0.140 & -0.640 & 0.117 & & & & & & & & \\
\hline Ln(TD)*Auto & -0.995 & 0.328 & -0.828 & 0.516 & & & & & & & & \\
\hline Ln(Trailer Share) & & & & & -0.367 & 0.053 & -0.168 & 0.043 & -0.367 & 0.054 & -0.159 & 0.044 \\
\hline Ln(Trucks/Area) & & & & & -0.400 & 0.072 & -0.664 & 0.061 & & & & \\
\hline$-\log L$ & \multicolumn{4}{|c|}{8140} & \multicolumn{4}{|c|}{8134} & \multicolumn{4}{|c|}{8016} \\
\hline \multicolumn{13}{|l|}{ Long Haul Only } \\
\hline Ln(TD)*Ref. Van & -0.366 & 0.090 & -0.500 & 0.090 & & & & & & & & \\
\hline Ln(TD)*Basic Van & -0.516 & 0.064 & -0.682 & 0.066 & & & & & & & & \\
\hline Ln(TD)*Platform & -0.214 & 0.105 & -0.156 & 0.104 & & & & & & & & \\
\hline Ln(TD)^Spec. Trail. & -0.223 & 0.120 & -0.192 & 0.097 & & & & & & & & \\
\hline Ln(TD)`Tank & 0.080 & 0.091 & -0.102 & 0.090 & & & & & & & & \\
\hline Ln(TD)^Spec. Van & -0.758 & 0.097 & -0.442 & 0.103 & & & & & & & & \\
\hline Ln(TD)*Dump & -0.936 & 0.264 & -0.319 & 0.256 & & & & & & & & \\
\hline Ln(TD)^Auto & -0.687 & 0.227 & -1.616 & 0.348 & & & & & & & & \\
\hline Ln(Trailer Share) & & & & & -0.531 & 0.046 & -0.456 & 0.046 & -0.365 & 0.048 & -0.330 & 0.047 \\
\hline Ln(Trucks/Area) & & & & & -0.201 & 0.058 & -0.376 & 0.057 & & & & \\
\hline -LogL & \multicolumn{4}{|c|}{13464} & \multicolumn{4}{|c|}{13502} & \multicolumn{4}{|c|}{13282} \\
\hline State Fixed Effects? & \multicolumn{4}{|c|}{ No } & \multicolumn{4}{|c|}{ No } & \multicolumn{4}{|c|}{ Yes } \\
\hline
\end{tabular}

Notes: All specifications include constants, a mixed cargo dummy, trailer dummies, and distance from home dummies, not reported here.

$\mathrm{N}=10387$ and 12600 for medium and long-haul specifications, respectively. $\mathrm{N}=7653$ for the first short haul specification; observations of auto trailers are dropped because the $\operatorname{Ln}(T D)^{\star}$ Auto parameters are not identified. $\mathrm{N}=7653$ for the other short haul specifications.

The parameters on the 49 state fixed effects are constrained to be equal across the two margins in the specifications reported in the right panel. 


\section{Table 8}

Rail Share, (1-Truck Share) Regressions

Product Class

Dependent Variable Rail Share 1-Truck Share

C

$\begin{array}{ll}-0.016 & -0.050 \\ 0.065 & 0.047\end{array}$

Trailer Share

$0.287 \quad \mathbf{0 . 7 3 3}$

$0.363 \quad 0.263$

Average Distance

$0.007 \quad 0.006$

$0.011 \quad 0.010$

$\begin{array}{lll}N & 29 & 36\end{array}$

R-Squared

$\begin{array}{ll}29 & 36 \\ 0.04 & 0.18\end{array}$

Primary Metal

Rail Share 1-Truck Share

$\begin{array}{ll}0.009 & 0.114 \\ 0.120 & 0.126 \\ & \\ -0.483 & -0.002 \\ 0.721 & 0.807 \\ & \\ 0.044 & 0.031 \\ 0.034 & 0.036\end{array}$

32

0.06

0.02

Lumber, Primary Metals

Rail Share 1-Truck Share

$\begin{array}{ll}-0.036 & 0.069 \\ 0.109 & 0.067 \\ & \\ 0.163 & 0.700 \\ 0.541 & 0.381 \\ & \\ 0.048 & -0.024 \\ 0.037 & 0.017\end{array}$

22

0.09

34

0.07

Note: Average Distance is in hundreds of miles.

Data are from 1993 Commodity Flow Survey CD-Rom.

Bold denotes statistical significance using a one-tailed t-test of size 0.05 ; italic denotes significance of a t-test of size 0.1 


\section{Table 9}

Ordered Logits - 1992: Selected Coefficients

Dependent Variable: Governance Form

\begin{tabular}{|c|c|c|c|c|c|c|}
\hline Margin & \multicolumn{2}{|c|}{ Short Haul Only } & \multicolumn{2}{|c|}{ Medium Haul Only } & \multicolumn{2}{|c|}{ Long Haul Only } \\
\hline $\begin{array}{l}\text { Ln(Trailer Share) } \\
\text { Ln(Trucks/Area) } \\
\text { Ln(Outbound/Inbound) }\end{array}$ & $\begin{array}{l}-0.066 \\
-0.594 \\
18.180\end{array}$ & $\begin{array}{l}0.079 \\
\mathbf{0 . 1 1 1} \\
\mathbf{3 . 3 0 7}\end{array}$ & $\begin{array}{r}-0.345 \\
-0.301 \\
3.849\end{array}$ & $\begin{array}{l}0.053 \\
0.079 \\
2.444\end{array}$ & $\begin{array}{r}-0.506 \\
-0.097 \\
3.043\end{array}$ & $\begin{array}{l}\mathbf{0 . 0 4 7} \\
0.062 \\
1.996\end{array}$ \\
\hline $\begin{array}{l}-\log L \\
N\end{array}$ & & & & & & \\
\hline
\end{tabular}

Note:

In the bottom panel, 49 state fixed effects are include 
Figure 1

Governance Share, Short Haul Trucks

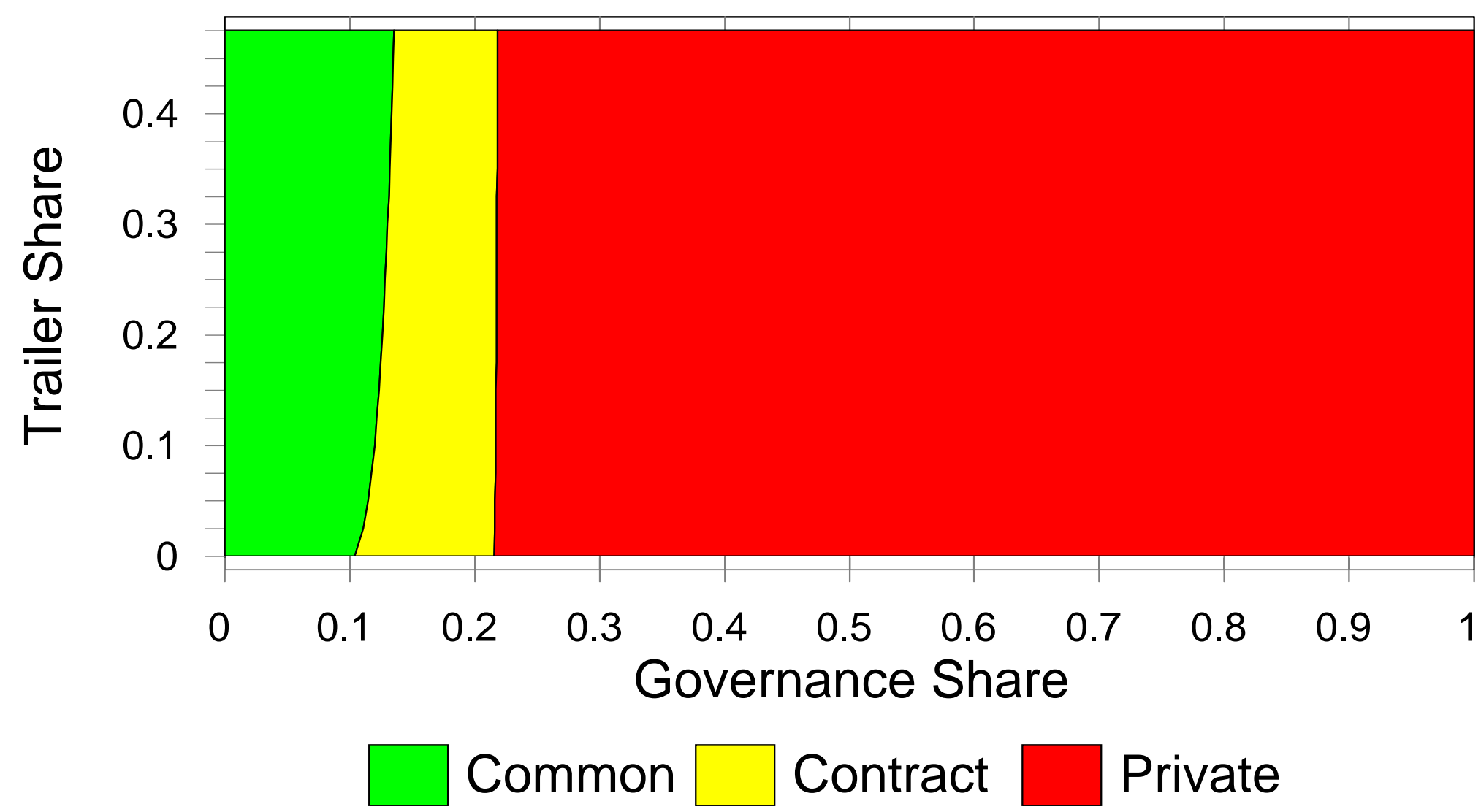


Figure 2

Governance Share, Long Haul Trucks

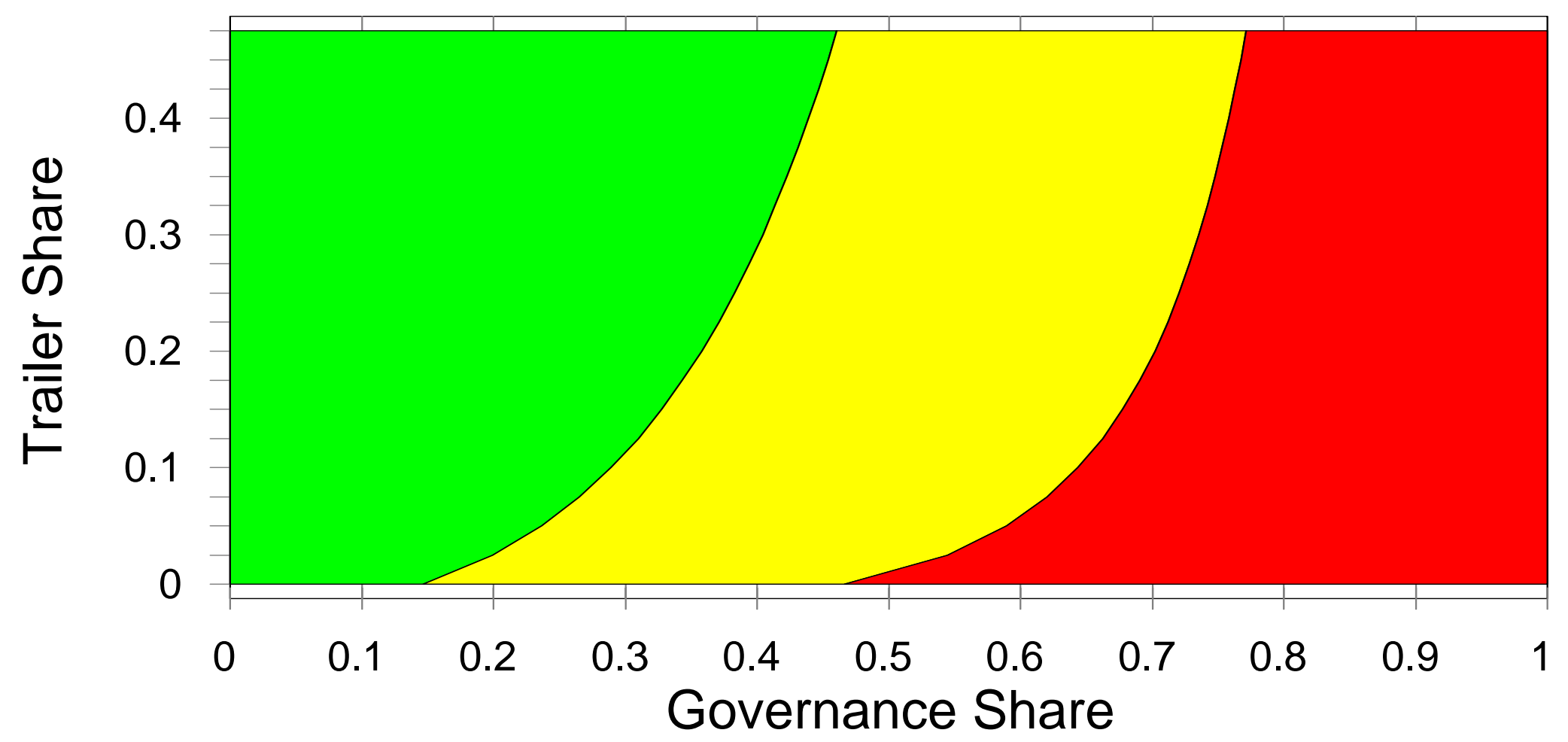

Common $\square$ Contract $\square$ Private 